\title{
Para pensar o acesso cognitivo à informação no Brasil
}

\author{
Thoughts on cognitive access to \\ information in Brazil
}

\author{
Maria Cristiane Barbosa Galvão \\ Professora do Departamento de Medicina Social/Faculdade de Medicina de \\ Ribeirão Preto/Universidade de São Paulo \\ mgalvao@usp.br
}

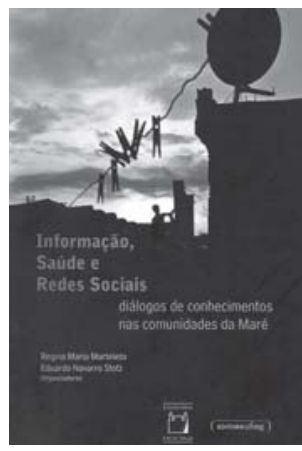

MARTELETO, Regina Maria; STOTZ, Eduardo Navarro (Org). Informação, saúde e redes sociais: diálogos de conhecimentos nas comunidades da Maré. Rio de Janeiro: Editora Fiocruz; Belo Horizonte: Editora UFMG, 2009. $176 p$.
$\mathrm{A}$ s mais de 17 vozes dos autores desse livro, dos vários autores que fornecem os pilares de suas fundamentações teóricas, das vozes sociais sistematizadas nos diversos estudos e metodologias, além da voz de seu prefácio, rica e crítica tanto em poética quanto em ciência, estão em consonância com a revisão contemporânea dos processos de divulgação científica e construção do conhecimento, que foca com propriedade as dimensões sociais e coletivas.

O livro é composto por três partes: As Teorias Implicadas no Conhecimento, As Formas de Construir o Conhecimento e Conhecimento e Práticas de Intervenção Socioculturais. A primeira delas compreende dois capítulos, "Redes sociais e saúde" e "Conhecimentos e conhecedores", que delimitam e explicitam o conceito de redes sociais, bem como apresentam a necessária inserção e construção da ciência em prol da emancipação humana. A segunda parte congrega três capítulos "Sujeitos do conhecimento", "Almanaque da dengue" e "Semeando ideias", que sistematizam, respectivamente, reflexões coletivas desencadeadas por vivências e intercâmbio de experiências em grupo, construção de um hipertexto popular, e o processo de apropriação de conhecimentos e a sistematização de práticas culturais. A última parte é composta por quatro capítulos, "Associativismo e redes sociais na Maré", "Janelas para o conhecimento", "Construção de conhecimento na formação de redes sociopedagógicas" e "Luíza, Gabriela e Joana", que encerram o livro avançando na proposição de uma teoria e uma ciência que conversem, sob diferentes perspectivas, com a realidade e a sociedade, transformando-as.

Cito aqui os títulos das partes e dos capítulos do livro por causa de sua notável consonância com os conteúdos abordados, evidenciando uma qualidade do livro, qual seja, sua honestidade científica e ética ao trazer resultados inovadores e essenciais para a compreensão das redes sociais em saúde, sem criar falsas expectativas no leitor. Estão reunidos no livro textos bem escritos, atualizados, bem fundamentados, de agradável leitura, honestos e comprometidos com as camadas menos favorecidas da população. Há que destacar também 
que os textos são resultantes de uma construção interdisciplinar, na qual autores de diversos campos agregam abordagens complementares e harmônicas.

Recomenda-se a leitura do livro para alunos de graduação, pós-graduação e pesquisadores de diversas áreas do conhecimento, entre elas ciência da informação, educação, ciências sociais, comunicação social e ciências da saúde. Especialmente, a obra é profícua em debates que podem ser abordados em disciplinas e estudos voltados para a transferência da informação e do conhecimento, disseminação da informação e do conhecimento, divulgação científica, comunicação científica em saúde, fontes de informação, serviços de informação e disciplinas que estudam a linguagem geral e a linguagem de especialidade. Para as instituições com atividades voltadas para o acesso cognitivo da informação e do conhecimento, a obra traz subsídios interessantes para novas ações e projetos.

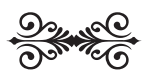

